\author{
Michał Bernardelli* \\ Mariusz Próchniak** \\ Bartosz Witkowski***
}

\title{
KONWERGENCJA DOCHODOWA: MOCNE I SŁABE STRONY ISTNIEJĄCYCH PODEJŚĆ
}

\section{Wprowadzenie}

Zgodnie z hipotezą konwergencji kraje słabiej rozwinięte rozwijają się szybciej niż kraje wyżej rozwinięte i dzięki temu zbliżają się do nich stopniowo pod względem poziomu rozwoju. W szczególności dotyczy to przeciętnego poziomu dochodu na mieszkańca. Doszukując się źródeł takiego wniosku, należy odnieść się wprost do neoklasycznych modeli wzrostu gospodarczego, z których wynika, że kraje słabiej rozwinięte, dysponując relatywnie mniejszą ilością kapitału (przy dostatecznej ilości i jakości innych czynników produkcji), oferują wyższą stopę zwrotu z inwestycji, co z kolei przyciąga inwestycje zagraniczne, zapewniając większy przyrost kapitału produkcyjnego, a w konsekwencji szybszy wzrost gospodarczy. Trzeba jednak podkreślić, że wniosek ten jest prawdziwy przy założeniu, że gospodarki rozpatrywanych krajów są otwarte i dysponują zbliżonym poziomem techniki produkcji, kultury organizacyjnej i kwalifikacji pracowników - swoboda przepływu myśli technicznej i kapitału są warunkami koniecznymi do wystąpienia konwergencji. Model Solowa implikuje istnienie tendencji do wyrównywania poziomów dochodu pod warunkiem, że rozważane gospodarki dążą do tego samego stanu równowagi długookresowej (steady-state). Teoretyczne objaśnienie zjawiska konwergencji na gruncie

* Kolegium Analiz Ekonomicznych, Szkoła Główna Handlowa w Warszawie.

* Kolegium Gospodarki Światowej, Szkoła Główna Handlowa w Warszawie.

*** Kolegium Analiz Ekonomicznych, Szkoła Główna Handlowa w Warszawie.

1 Projekt został sfinansowany ze środków Narodowego Centrum Nauki (nr rejestracyjny projektu: 2015/19/B/HS4/00362). 
neoklasycznego modelu wzrostu przedstawili jako jedni z pierwszych Sala-i-Martin ${ }^{2}$ oraz Barro i Sala-i-Martin ${ }^{3}$.

Wspomniana swoboda przepływu myśli i kapitału otwiera drogę do wskazania innego źródła wystąpienia procesów konwergencyjnych. Nowa technika, powstająca głównie w krajach wysoko rozwiniętych, wymaga ogromnych nakładów na badania i rozwój oraz na wykształcenie i utrzymanie kadry naukowo-badawczej. Jednakże odkrycie nowych produktów i technologii szybko prowokuje ich przepływ do pozostałych krajów, stymulowany przez handel międzynarodowy i działalność międzynarodowych korporacji, napływ zagranicznych inwestycji, sprzedaż licencji czy też zwyczajne przechwytywanie, adaptację i imitację cudzych wynalazków. W rezultacie kraje słabiej rozwinięte stają się beneficjentami, ale nie inicjatorami rozwoju. Zyskują na nim, nie ponosząc kosztów, korzystając nieodpłatnie lub za stosunkowo niewielką cenę z transferu zagranicznej technologii. Mogą więc przeznaczyć swoje zasoby inwestycyjne na inne cele, $w$ tym na rozbudowę aparatu wytwórczego oraz zwiększanie technicznego uzbrojenia pracy, a w konsekwencji rozwijać się szybciej.

Powyższe podstawy ekonomiczne konwergencji, które w skrócie można określić terminem „naśladownictwo”, nie są jedyną ekonomiczną przyczyną konwergencji. Równie istotna jest sama natura procesów ekonomicznych i występowanie malejących krańcowych przychodów z czynników wytwórczych. Neoklasyczna funkcja produkcji, która występuje w neoklasycznych modelach wzrostu gospodarczego (m.in. modelu Solowa, modelu Ramseya czy też modelu Diamonda), zakłada m.in. malejący krańcowy produkt kapitału i stałe przychody ze skali. Oznacza to, że w przypadku krajów słabo rozwiniętych dany strumień inwestycji (przyrostu kapitału) powoduje większe przyrosty produkcji niż w krajach wyżej rozwiniętych. W efekcie, przy założeniu ceteris paribus, kraje biedniejsze będą wykazywać szybsze tempo wzrostu gospodarczego niż kraje bogatsze. Oczywiście mechanizm ten będzie działał tylko w sytuacji malejącej krańcowej produktywności „odtwarzalnych” czynników wytwórczych (na poziomie całej gospodarki) i np. w endogenicznych modelach wzrostu gospodarczego, które zakładają występowanie co najmniej stałych przychodów z odtwarzalnych czynników wytwórczych, konwergencja zazwyczaj nie występuje (a w niektórych modelach endogenicznych mogą się nawet pojawić tendencje dywergencyjne).

Jeszcze inną przyczyną wyrównywania się poziomów dochodu są działania o charakterze politycznym prowadzące do redystrybucji dochodów i stymulowania wzrostu gospodarczego biedniejszych krajów i regionów. Z polityką taką mamy zwłaszcza

2 X. Sala-i-Martin, The Classical Approach to Convergence Analysis, „Economic Journal” No. 106, 1996, s. $1019-1036$.

3 R. Barro, X. Sala-i-Martin, Convergence, „Journal of Political Economy” No. 100, 1992, s. 223-251. 
do czynienia w Unii Europejskiej. Fundusze strukturalne UE, mające na celu zmniejszenie różnic dochodowych między niżej i wyżej rozwiniętymi krajami Wspólnoty, były niewątpliwie bardzo ważną przyczyną istnienia zbieżności poziomu dochodów wśród krajów Unii.

Występowanie procesów konwergencyjnych w przypadku większości gospodarek, czy raczej ich tworzonych według racjonalnego klucza grup, może więc być uzasadnione wnioskami z modelu makroekonomicznego, jak też i w oparciu o ekonomiczną racjonalność. Jednocześnie sam problem jest na tyle istotny, że proste stwierdzenie ich istnienia nie jest $\mathrm{z}$ reguły wystarczające. Badacze analizują, jakie jest natężenie procesów, a także jakie uwarunkowania mogą im sprzyjać. W tym kontekście ogólne pojęcie zbieżności zostaje zastąpione jej określonymi typami, zaś metody weryfikacji i pomiaru z czasem stają się coraz bardziej wysublimowane. W konsekwencji dziś w literaturze istnieje wiele definicji realnej konwergencji gospodarczej oraz wiele metod wykorzystywanych przy badaniu tego zjawiska. Wystarczy przytoczyć Islama ${ }^{4}$, który wyodrębnia 7 następujących koncepcji podziału zjawiska realnej konwergencji: a) zbieżność w ramach jednej gospodarki i zbieżność między gospodarkami, b) zbieżność stóp wzrostu i zbieżność poziomu dochodów, c) zbieżność $\beta$ i zbieżność $\sigma$, d) zbieżność absolutna i zbieżność warunkowa, e) zbieżność globalna i zbieżność lokalna, f) zbieżność dochodowa i zbieżność TFP, g) zbieżność deterministyczna i zbieżność stochastyczna. Jednocześnie należy nadmienić, że już w momencie, gdy Islam pisał te słowa, liczba zaproponowanych w literaturze podejść nie była ograniczona jedynie do najbardziej popularnych zbieżności $\beta$ i zbieżności $\sigma$, z czasem zaś pojawiały się kolejne. Podobnie metody wnioskowania o ich występowaniu z czasem są coraz bardziej wyrafinowane, tak by umożliwić ich uodpornienie na coraz to kolejne zakłócenia zewnętrzne.

Celem artykułu jest wskazanie kilku głównych kwestii powodujących, że często obserwacja tych samych danych przez różnych autorów prowadzi ich do rozbieżnych wniosków odnośnie do występowania konwergencji, nie mówiąc już o jej natężeniu. Kolejno więc omawiamy kwestie różnych rodzajów konwergencji, niestabilności w czasie i załamań strukturalnych oraz problemów z zestawem zmiennych kontrolnych w modelu konwergencji warunkowej.

4 N. Islam, What Have We Learnt from the Convergence Debate?, „Journal of Economic Surveys” No. 17, 2003, s. 309-362. 


\section{Podejścia do konwergencji}

Najszerzej stosowane w analizie konwergencji podejścia to niewątpliwie wprowadzone przez Sala-i-Martina w jego pracy doktorskiej z 1990 r. konwergencja typu $\beta$ oraz konwergencja typu $\sigma, z$ wyraźną przewagą tego pierwszego.

Konwergencja $\beta$ występuje, gdy kraje słabiej rozwinięte (o niższym poziomie PKB na mieszkańca) wykazują szybsze tempo wzrostu gospodarczego niż kraje wyżej rozwinięte (o wyższym poziomie PKB na mieszkańca). W badaniach empirycznych autorzy dokonują weryfikacji występowania konwergencji oraz estymacji współczynnika $\beta$ na podstawie danych empirycznych dla wielu gospodarek. Typową metodą weryfikacji występowania konwergencji typu $\beta$ jest zastosowanie tzw. regresji typu Barro ${ }^{5}$. Idea takiego podejścia polega na estymacji regresji, w której rolę zmiennej zależnej pełni wzrost PKB w analizowanym okresie, zaś zmiennej objaśniającej - wartość PKB w okresie początkowym. Łatwo zauważyć, że w konsekwencji można wnioskować, iż przedmiotowa konwergencja ma miejsce, jeśli w tak określonej regresji otrzymujemy ujemne oszacowanie współczynnika nachylenia. Jednocześnie jednak, nawet tak, wydawałoby się, proste i powszechnie stosowane podejście doczekało się szybkiej krytyki. Friedman ${ }^{6}$ oraz Quah $^{7}$ wskazali, że stosowanie podejścia Barro może często prowadzić do obciążenia estymatora parametru konwergencji. W zamian Friedman sugeruje wykorzystanie współczynnika zmienności PKB per capita, zaś Quah opisuje podejście umożliwiające uchwycenie pełnej dynamiki międzykrajowych rozkładów PKB per capita. Pomimo to podejście oparte na regresji Barro do dziś pozostaje najbardziej popularne i doczekało się kolejnych rozszerzeń, np. na skutek wykorzystania do modelowania konwergencji danych panelowych.

Konwergencja $\sigma$ ma miejsce, gdy zróżnicowanie poziomów PKB na mieszkańca między krajami maleje w czasie. Oznacza to, że na poziomie operacyjnym naturalną metodą badania występowania tego rodzaju konwergencji jest uzależnienie wybranej miary dyspersji (np. odchylenia standardowego lub wariancji PKB per capita) od trendu i weryfikacja, czy można uznać wartość miary dyspersji za istotnie w sensie statystycznym malejącą w czasie. Już samo określenie „wybranej miary dyspersji” pozostawia pewną swobodę i powoduje, że w konsekwencji otrzymane wyniki nie zawsze są jednoznaczne i pokrywają się co do wniosków między ich autorami. Mimo

5 R.J. Barro, Economic Growth in a Cross Section of Countries, „Quarterly Journal of Economics” No. 106, 1991, s. 407-443.

6 M.J. Friedman, Do Old Fallacies Ever Die?, „Journal of Economic Literature” No. 30, 1992, s. 2129-2132.

D.T. Quah, Galton's Fallacy and Tests of the Convergence Hypothesis, „Scandinavian Journal of Economics" No. 95, 1993, s. 427-443. 
że w tym miejscu typowo wykorzystywana jest wariancja, a odchylenie standardowe nieznacznie ustępuje jej popularnością, różnego rodzaju problemy z obserwacjami odstającymi prowokują wykorzystanie zamiennie pozycyjnych miar zmienności, aby wyeliminować zniekształcenia wniosków na skutek wystąpienia jednej, lecz skrajnie nietypowej obserwacji.

Mimo że wśród obecnych w literaturze procesów konwergencji to konwergencja typu $\beta$ doczekała się największej liczby publikacji i zastosowań $\mathrm{w}$ analizach oraz wydaje się najlepiej umotywowana z punktu widzenia teoretycznego, w literaturze można napotkać koncepcje zbliżone, ale niepokrywające się z ideą konwergencji typu $\beta$, jednak z pewnymi zmianami. Przykładem takiego typu konwergencji jest konwergencja $\gamma$ (gamma). Boyle i McCarthy ${ }^{8}$ zaproponowali oparcie wnioskowania nie tyle na zmienności i malejącym rozstępie PKB w czasie, ale na pozycji, jaką zajmuje dany kraj pod względem PKB w określonej populacji państw. Jeśliby bowiem ranking wybranego kraju pozostawał niezmieniony w czasie, można byłoby uznać, że nie dochodzi do zbieżności. Nasuwa to na myśl wykorzystanie jednej z miar opartych na rangowaniu. W tym przypadku jako wskaźnika pozwalającego na weryfikację stabilności rang w czasie Boyle i McCarthy zaproponowali użycie indeksu zgodności rang Kendalla. Wieloletnia wersja wskaźnika $R C_{t}$, w której wykorzystana zostaje informacja o zmienności w okresie między rokiem 0 a rokiem $t$, może być wyznaczona w oparciu o ruchomą sumę okresów:

$$
R C_{t}=\frac{\operatorname{Var} \sum_{t=0}^{T} A R(Y)_{i t}}{\operatorname{Var}\left((T+1) \cdot A R(Y)_{i 0}\right)}
$$

gdzie $A R(Y)_{i t}$ oznacza pozycję w rankingu PKB kraju $i$-tego w roku $t$ (i, analogicznie, $A R(Y)_{i 0}$ to pozycja kraju $i$-tego w roku 0 ), zaś $T+1$ to liczba lat, $\mathrm{z}$ których dane wykorzystano do utworzenia indeksu. Alternatywnie możliwe jest utworzenie binarnej wersji wskaźnika, $R C a_{t}$, w której wykorzystuje się jedynie różnicę o rozbieżności rankingu między dokładnie dwoma okresami: rokiem 0 i rokiem $t$ :

$$
R C a_{t}=\frac{\operatorname{Var}\left(A R(Y)_{i t}+A R(Y)_{i 0}\right)}{\operatorname{Var}\left(2 A R(Y)_{i 0}\right)}
$$

„Wieloletnia” wersja $R C a_{t}$ wykorzystująca wszystkie możliwe do utworzenia kombinacje dwóch porównywanych okresów (0 i $t$ ), a więc oparta na uśrednieniu

8 G.E. Boyle, T.G. McCarthy, A Simple Measure of $\beta$-Convergence, „Oxford Bulletin Economics and Statistics" No. 59, 1997, s. 257-264. 
wszystkich możliwych do utworzenia $R C a_{t}$ dla poszczególnych $i, t, 0$, określana jest mianem współczynnika konwergencji typu $\gamma$ (gamma). Jak łatwo zauważyć, z konstrukcji miary wynika jej nieparametryczność, a tym samym - odporność wnioskowania na obserwacje skrajne. Biorąc pod uwagę zakres wartości, jakie może przyjmować indeks Kendalla w przedziale $<0 ; 1>$, oraz fakt, że bliskość miary do 1 oznacza stabilność rankingu w czasie, należy uznać, że bliska 1 wartość wskaźnika konwergencji gamma będzie prowadzić do wniosku o braku konwergencji w tym sensie.

Lucke $^{9}$ zaproponował świeżą koncepcję, określoną mianem konwergencji typu $\rho$ (rho). Jego idea oparta jest na takim przeformułowaniu szeregów czasowych, by odwrócić ich chronologię, a jednocześnie rozważyć procesy dywergencyjne, analogiczne koncepcyjne do idei $\beta$. W ten sposób, zamiast badać występowanie konwergencji w czasie postępującym, badamy występowanie dywergencji w czasie odwróconym. Jak pokazuje Lucke ${ }^{10}$, takie podejście nie jest bynajmniej synonimiczne do klasycznego, a przeciwnie - nieco bardziej restrykcyjne są wymagania, które muszą być spełnione, by można było potwierdzić występowanie konwergencji w proponowanym przez niego sensie.

Należy zauważyć, że generalnie wszystkie z omówionych tu czterech podejść oparte były na obserwacji sytuacji bieżącej i przeszłej. Starsze narzędzia analizy konwergencji typu $\beta$ opierały wnioskowanie jedynie na danych przekrojowych, zaś konwergencji typu $\sigma$ - jedynie na szeregu czasowym. Obecnie od lat dostępne rozwiązania oparte są $\mathrm{w}$ większości na panelu złożonym $\mathrm{z}$ szerszej grupy analizowanych państw. W konsekwencji stosowane metody są znacznie bardziej wysublimowane. Wciąż jednak opierają się raczej na obserwacji stanu bieżącego, a nie na wnioskowaniu o charakterze probabilistycznym, ukierunkowanym na spodziewaną w przyszłości ścieżkę czasową rozważanych procesów. Na tym tle od powyższych odróżnia się koncepcja konwergencji stochastycznej, sformułowana jeszcze w latach 90. poprzedniego stulecia. Opierając się na definicji Bernarda i Durlaufa ${ }^{11}$, możemy stwierdzić, że występuje konwergencja stochastyczna kraju $i$ oraz kraju $j$, jeśli

$$
\lim _{k \rightarrow \infty}\left(\ln G D P_{i, t+k}-\ln G D P_{j, t+k} \mid I_{t}\right)=0
$$

gdzie $I_{t}$ oznacza zbiór informacji dostępnych w momencie $t$, zaś $\ln G D P_{i, t}$ jest logarytmem naturalnym PKB kraju $i$-tego w okresie $t$ (najczęściej wyrażanego per capita, według PPP). Wielu badaczy zamienia zero występujące po prawej stronie powyższego

\footnotetext{
9 B. Lucke, $\rho$-Convergence, „Economics Letters” No. 99, 2008, s. 439-442.

10 Ibidem.

11 A.B. Bernard, S.N. Durlauf, Convergence in International Output, „Journal of Applied Econometrics” No. 10,1995 , s. $97-108$.
} 
warunku przez dowolną stałą, mówiąc wówczas nie tyle o występowaniu stricte konwergencji, lecz tzw. wspólnych trendów, co koncepcyjnie jest bliskie idei konwergencji cyklicznej (synchronizacji cykli).

Od strony ekonometrycznej weryfikacja występowania konwergencji stochastycznej oparta jest dla przypadku dwuwymiarowego na wyznaczeniu szeregu różnic między PKB w pojedynczych okresach między krajem $i$-tym a krajem $j$-tym:

$$
d G D P_{i j, t}=\ln G D P_{i, t}-\ln G D P_{j, t}
$$

a następnie weryfikacji stacjonarności szeregu $d G D P_{i j, t}, \mathrm{z}$ reguły z wykorzystaniem testu opartego na jednej z wersji ADF, choć Pesaran ${ }^{12}$ sugeruje, że z uwagi na jego niską moc lepszym rozwiązaniem jest wykorzystanie testu klasy KPSS.

Jak zatem widać, w literaturze można wskazać co najmniej pięć wymienianych różnych rodzajów konwergencji w miejscu, gdzie Islam wspominał o dwóch. Wprawdzie wciąż jedynie część z nich występuje w badaniach regularnie, jednak na przykład Batóg ${ }^{13}$ - w książce poświęconej w całości analizie konwergencji poziomów dochodu w UE - stosuje wiele różnych ( $w$ tym zaawansowanych) metod ekonometrycznych do weryfikacji kilku rodzajów konwergencji: oprócz standardowej zbieżności $\beta$ i $\sigma$ także typu $\gamma$. Wykorzystując obszerne badania empiryczne, autor pozytywnie weryfikuje hipotezę o występowaniu konwergencji w krajach UE, stwierdzając jednak, że proces zmniejszania dystansu rozwojowego będzie trwał jeszcze wiele lat. W konsekwencji więc także w polskich badaniach można wskazać na obecność nie tylko konwergencji typu $\beta$ w analizach. Dodatkowo warto zauważyć, iż wnioski z badań mogą być uzależnione od poziomu dezagregacji geograficznej - o ile większość przytaczanych tu prac dotyczy zbieżności na poziomie krajów, o tyle np. Gajewski i Tokarski ${ }^{14}$ analizują procesy konwergencyjne na poziomie regionów.

Już na gruncie najbardziej ogólnych koncepcji można zadać sobie pytanie, czy poszczególne wymienione typy konwergencji współwystępują? Czy możliwa jest sytuacja, w której występuje zaledwie część ze wskazanych rodzajów konwergencji, pozostałe zaś nie są empirycznie potwierdzone, a jeśli tak, to czy należy uznać, że dochodzi - czy też nie - do zbieżności między rozważanymi krajami? Wydaje się, że na tak postawione pytanie trudno w tym momencie udzielić jednoznacznej i ogólnej

12 M.H. Pesaran, A Pair-wise Approach to Testing for Output and Growth Convergence, „Journal of Econometrics" No. 138, 2007, s. 312-355.

13 J. Batóg, Konwergencja dochodowa w krajach Unii Europejskiej, Wydawnictwo Naukowe USz, Szczecin 2010.

14 P. Gajewski, T. Tokarski, Czy w Polsce występuje efekt konwergencji regionalnej?, „Studia Ekonomiczne” nr 1-2, 2004, s. 45-70. 
odpowiedzi, choć można udzielić odpowiedzi cząstkowych. Jak pokazuje Lucke ${ }^{15}$, wystąpienie konwergencji typu $\rho$ implikuje występowanie konwergencji typu $\sigma$, choć rozumowanie odwrotne nie jest już prawdziwe. $Z$ kolei Furceri ${ }^{16}$ pokazuje od strony teoretycznej, że warunkiem koniecznym - choć nie dostatecznym - wystąpienia konwergencji typu $\sigma$ jest obecność konwergencji typu $\beta$. Mimo wszystko badania empiryczne nie w pełni potwierdzają ten fakt, choć można stwierdzić, że winę za ten stan rzeczy ponosi słabość narzędzi analitycznych i - z reguły - niewielka długość analizowanych szeregów czasowych. Nie zmienia to jednak faktu, że brakuje badań empirycznych, które mogłyby prowadzić do bardziej ogólnych wniosków na temat wzajemnych powiązań między poszczególnymi typami konwergencji, a zwłaszcza zasugerować tryb postępowania w sytuacji, w której stwierdzamy występowanie jednego rodzaju konwergencji, lecz jednocześnie brak innego rodzaju.

\section{Konwergencja warunkowa i absolutna}

Ponownie już Islam ${ }^{17}$ zwrócił uwagę na obecny już wcześniej w literaturze problem różnicy między konwergencją absolutną i konwergencją warunkową. Konwergencja o charakterze absolutnym występuje wtedy, gdy dochodzi do zbieżności bezpośrednio między obserwowanymi szeregami PKB (w zastosowanym ujęciu). Z drugiej strony, odnosząc się do konwergencji typu $\beta$, konwergencja warunkowa ma miejsce, jeśli w modelu regresji typu Barro jako dodatkowe czynniki zostaną uwzględnione inne czynniki wzrostu gospodarczego. Wówczas na podstawie modelu można wnioskować, że zbieżność występuje ceteris paribus względem uwzględnionych w równaniu czynników wzrostu. Nawet w mocno ograniczonej populacji badanych krajów stwierdzenie konwergencji absolutnej często nie ma miejsca, choćby na skutek znacząco inaczej prowadzonej polityki gospodarczej przez rozpatrywane kraje. Uwzględnienie tego jako czynników w konstruowanym modelu i - tym sposobem - ich wyegzogenizowanie - pozwala na konkluzję, iż gdyby prowadzona polityka gospodarcza była taka sama, wówczas doszłoby do konwergencji o charakterze absolutnym.

Od strony technicznej, w przypadku konwergencji typu $\beta$, zastosowanie odpowiedniego rozwiązania sprowadza się do uwzględnienia w równaniu regresji typu Barro odpowiedniej grupy czynników wzrostu. Niewielu autorów prowadzi analogiczne

\footnotetext{
15 B. Lucke, op.cit.

16 D. Furceri, $\beta$ and $\sigma$-convergence: A Mathematical Relation of Causality, „Economics Letters” No. 89, 2005 , s. $212-215$.

17 N. Islam, op.cit.
} 
analizy konwergencji warunkowej w odniesieniu do innych typów konwergencji. W tym miejscu można wspomnieć pracę Próchniaka i Witkowskiego ${ }^{18}$, którzy prowadzą zbliżoną koncepcyjnie analizę dla konwergencji stochastycznej, dokonując oczyszczenia szeregu PKB poprzez eliminację wpływu, jaki miały nań inne czynniki, typowo traktowane jako czynniki wzrostu PKB.

$\mathrm{W}$ tym miejscu należy zwrócić uwagę na daleko posuniętą niejednoznaczność określenia „typowe czynniki wzrostu”. W zależności od listy zmiennych użytych w modelu, możliwe jest dojście do ekstremalnie różnych wniosków w obszarze już nie tylko natężenia, ale wręcz samego występowania procesu konwergencji warunkowej, zaś ostateczny wniosek staje się w dużym stopniu uzależniony od subiektywnej opinii badacza. Aby rozstrzygnąć tę kwestię w sposób choć częściowo obiektywny, Sala-i-Martin, Doppelhofer i Miller ${ }^{19}$ jako rozwiązanie tego problemu stosują podejście określane mianem bayesowskiego uśredniania oszacowań (bayesian averaging of classical estimates - BACE). Ideę BACE, choć bez użycia tej właśnie nazwy, sformułował Sala-i-Martin ${ }^{20}$. W swojej pracy zasugerował odejście od prób obiektywizacji wniosków dotyczących odporności wyników o wpływie zmiennych objaśniających przy użyciu leamerowskiej extreme bound analysis.W zamian zaproponował podejście, w którym zamiast doboru zmiennych do pojedynczego modelu dokonuje się estymacji wielu modeli ze wszystkimi możliwymi do utworzenia zbiorami zmiennych objaśniających, spośród wytypowanych zmiennych kandydatek, następnie zaś w odpowiedni sposób uśrednia się uzyskane oszacowania. Rozwiązanie Sala-i-Martina, wykorzystane w późniejszym artykule Sala-i-Martina, Doppelhofera i Millera zawierającym pogłębione wnioskowania $\mathrm{w}$ odniesieniu między innymi do własności zastosowanego estymatora, zostało wykorzystane w prostym modelu opartym na danych przekrojowych, gdzie szacowana regresja miała postać typowej regresji liniowej, zaś do jej estymacji możliwe było wykorzystanie wprost klasycznej metody najmniejszych kwadratów. Uogólnienie problemu na przypadek danych panelowych utrudnia w znaczny sposób całość postępowania. Stosowane w modelach dynamicznych estymatory uogólnionej metody momentów wymagają bowiem znacznie bardziej skomplikowanego podejścia opartego na uogólnieniu BACE, znanym jako BMA (bayesian model averaging) - rozwiązanie to wdrożyli między innymi Próchniak i Witkowski ${ }^{21}$.

18 M. Próchniak, B. Witkowski, Stochastic Convergence of the European Union Countries: A Conditional Approach, „Roczniki Kolegium Analiz Ekonomicznych SGH” nr 39, 2015, s. 41-55.

19 X. Sala-i-Martin, G. Doppelhofer, R. Miller, Determinants of Long-Term Growth: A Bayesian Averaging of Classical Estimates (BACE) Approach, „American Economic Review” No. 94, 2004, s. 813-835.

20 X. Sala-i-Martin, I Just Ran Two Million Regressions, „American Economic Review” No. 87(2), 1997, s. $178-183$.

21 M. Próchniak, B. Witkowski, Time Stability of the Beta Convergence among EU Countries: Bayesian Model Averaging Perspective, „Economic Modeling” No. 30, 2013, s. 322-333. 
Oprócz wymienionych w literaturze można wskazać jeszcze kilka innych badań, w których wykorzystywane jest BMA w przypadku rozważań dotyczących wzrostu gospodarczego, choć kontekst rozważań jest nieco inny. Wspomniany przełomowy artykuł Sala-i-Martina, Doppelhofera i Millera skoncentrowany był na identyfikacji czynników wzrostu gospodarczego. Ich zbiór danych objął 98 państw obserwowanych w latach 1960-1992, z tym że każde z nich potraktowano jako pojedynczą obserwację, zbiór miał więc charakter danych przekrojowych. Jako potencjalne determinanty wzrostu gospodarczego badacze ci uwzględnili 67 czynników, traktując przy tym inicjalny poziom rozwoju ekwiwalentnie jak pozostałe czynniki. Oznacza to, że dopuścili oni możliwość, a nie pewność wystąpienia konwergencji PKB. W dalszej części pracy zidentyfikowali oni 18 zmiennych, które w odporny w sensie statystycznym sposób można było uznać za czynniki wzrostu, przy czym faktycznie najsilniejsze potwierdzenie znaleziono właśnie dla początkowego poziomu rozwoju, co stanowiło potwierdzenie hipotezy konwergencji (warunkowej). Wśród innych prac wykorzystujących omówioną technikę są także Crespo-Cuaresma i Doppelhofer ${ }^{22}$, którzy rozważali rozwiązanie problemu niestabilności w czasie. Z kolei Moral-Benito ${ }^{23}$ przeanalizował 73 gospodarki w okresie 1960-2000 podzielonym na pięcioletnie podokresy, również korzystając z BMA przy wnioskowaniu odnośnie do adekwatności czynników wzrostu. Ciccone i Jarociński ${ }^{24}$ użyli z kolei podejścia BACE $w$ takim ujęciu i na niemal tej samej bazie danych, której użyli Sala-i-Martin, Doppelhofer i Miller, pokazując przy tym, że ta metoda nie gwarantuje stabilności wyników w przypadku uzyskania danych z różnych źródeł. Wreszcie Próchniak i Witkowski ${ }^{25}$ przy użyciu BACE przeprowadzają analizę występowania konwergencji w grupie 127 państw w okresie 1970-2009 podzielonym na pięcioletnie podokresy, stwierdzając natężenie konwergencji na poziomie jej parametru rzędu około 1,3\%, choć po ograniczeniu analizy do grupy krajów transformacji ci sami autorzy szacują jej tempo na $1,7 \%{ }^{26}$. Trzeba jednak zauważyć, że koncepcja BMA wciąż jest relatywnie nowa i rzadko wykorzystywana $\mathrm{w}$ analizie konwergencji, wymaga więc dalszych intensywnych badań na tym polu, w szczególności w kontekście jej ewentualnego wykorzystania w analizie innych niż wspomniane tu rodzajów konwergencji względnej.

22 J. Crespo-Cuaresma, G. Doppelhofer, Nonlinearities in Cross-Country Growth Regressions: A Bayesian Averaging of Thresholds (BAT) Approach, „Journal of Macroeconomics” No. 29, 2007, s. 541-554.

23 E. Moral-Benito, Determinants of Economic Growth: A Bayesian Panel-Data Approach, „Working Paper” No. 719, CEMFI, Madrid 2010.

24 A. Ciccone, M. Jarociński, Determinants of Economic Growth: Will Data Tell?, „American Economic Journal: Macroeconomics" No. 2, 2010, s. 223-247.

25 M. Próchniak, B. Witkowski, Konwergencja gospodarcza typu $\beta w$ świetle bayesowskiego uśredniania oszacowań, „Bank i Kredyt” nr 43, 2012, s. 25-58.

26 M. Próchniak, B. Witkowski, Real $\beta$ Convergence o Transition Countries - Robust Approach, „Eastern European Economics" No. 51, 2013, s. 6-26. 


\section{Niestabilność w czasie}

Ostatnim spośród problemów, na które w artykule zwracamy szczególną uwagę, jest kwestia stabilności rozważanych procesów w czasie. U podstaw analizy większości rozpatrywanych typów konwergencji leży zależność, opisywana przy użyciu pewnego parametrycznego równania. W praktyce oznacza to, że stosując przykładowo model regresji typu Barro w jego klasycznej postaci, zakładamy, że zarówno wpływ innych czynników wzrostu, ujętych w równaniu, jak i tempo procesów konwergencyjnych są stałe w czasie. W rzeczywistości jednak tak przecież być nie musi: nie tylko samo tempo konwergencji nie musi być stałe. Możliwe jest wręcz, że proces łączący gospodarki wybranych krajów przez część badanego okresu miał charakter konwergencyjny o zróżnicowanym natężeniu, przez część zaś - charakter dywergencyjny. Gdyby tak się stało, estymacja pojedynczej zależności na całości zbioru danych nie tylko byłaby obarczona potencjalnie niemałym błędem, ale wręcz mogłaby sugerować istnienie tendencji dokładnie odwrotnych niż mające w rzeczywistości miejsce.

Dlatego też wydaje się istotne, by ewentualną niestabilność rozważanych procesów uwzględnić w analizie. Próbę taką podejmowali we wcześniejszych artykułach już Próchniak i Witkowski ${ }^{27}$. W tym celu wykorzystywali podejście oparte na wprowadzeniu do modelu regresji typu Barro interakcji wybranych, potencjalnie mających niestabilny w czasie wpływ na wzrost gospodarczy, zmiennych objaśniających bądź ze zmienną czasową, bądź z grupą zmiennych binarnych wyróżniających poszczególne okresy. W ten sposób w otrzymanym modelu możliwa była weryfikacja istotności statystycznej tak utworzonych interakcji, a przez to próba odpowiedzi na pytanie o stabilność procesów konwergencyjnych w czasie.

Istotną wadą takiego podejścia jest to, że konieczna jest albo jego dość silna parametryzacja poprzez wprowadzenie interakcji czynników wzrostu z elementem trendu określonego typu, co uniemożliwia arbitralne dopuszczenie różnego typu załamań na rynku w czasie, albo też, alternatywnie, możliwe jest dopuszczenie dość dużego stopnia liberalizacji i usunięcia założeń parametrycznych poprzez wprowadzenie interakcji czynników wzrostu z grupą kilku zmiennych zero-jedynkowych, wówczas jednak konieczne jest arbitralne założenie w jakich dokładnie momentach wystąpiły na rynku potencjalne załamania strukturalne.

Wydaje się jednak, że istnieje niewykorzystywana w literaturze, zaś możliwa do zastosowania metoda oparta na ukrytych modelach Markowa (hidden Markov models - HMM) - o ile bowiem w literaturze można napotkać przykłady wykorzystania

27 W: M. Próchniak, B. Witkowski, Time Stability..., op.cit. i późniejszych. 
procesów Markowa w analizie zjawiska zbieżności ${ }^{28}$, o tyle analizy oparte stricte na wykorzystaniu łańcuchów ukrytych wydają się nie istnieć. Metoda HMM jest w zasadzie pewną zaawansowaną kombinacją kilku algorytmów, takich jak algorytm Bauma-Welcha, Viterbiego oraz symulacji Monte Carlo. Wydaje się, że kluczowym problemem przy modelowaniu załamań strukturalnych spowodowanych szczytami i dołkami cykli koniunkturalnych jest brak możliwości obiektywnego założenia a priori momentu wystąpienia tych ekstremów. Tymczasem ideą HMM, stanowiących podstawę wielu algorytmów do analizy procesów i rozpoznawania wzorców (odręczne pismo, automatyzacja rozpoznawania mowy, sekwencjonowanie DNA), jest wyróżnienie dwóch warstw: widocznej (reprezentującej obserwowalną sekwencję symboli) oraz ukrytej (będącej sekwencją stanów, które nie są znane, a są celem rozpoznania). Tym samym możliwe jest ich wykorzystanie bez zakładania dokładnego kształtu procesu ukrytego. HMM znalazły także zastosowanie w analizie finansowych i makroekonomicznych szeregów czasowych ${ }^{29}$.Teoria ukrytych modeli Markowa może więc zostać wykorzystana do identyfikacji punktów zwrotnych cyklu koniunkturalnego, do badania synchronizacji tych cykli oraz do analizy wyrównywania się poziomu dochodów, zaś w metodzie HMM można uwzględnić m.in. roczne różnice między PKB per capita pojedynczego kraju a PKB per capita innego kraju, będącego punktem odniesienia, lub grupy krajów. W kolejnym etapie konwergencje typu $\beta, \sigma, \gamma, \rho$ oraz konwergencja stochastyczna mogą być już typowo analizowane $\mathrm{z}$ wykorzystaniem punktów zwrotnych uzyskanych na podstawie procedury HMM. W ten sposób możliwe wydaje się znaczące poprawienie stosowanego w literaturze wnioskowania poprzez dopuszczenie jego niestabilności w czasie, a bez jednoczesnego zakładania formy i momentu załamania.

\section{Podsumowanie}

Niniejszy artykuł zawiera skondensowany opis głównych słabych punktów, jakie autorzy widzą w obecnych w literaturze analizach zjawiska konwergencji, i stanowi podstawę do identyfikację tych kwestii, których rozwiązanie wydaje się kluczowe dla dalszego rozwoju analiz nad procesami zbieżności. Po pierwsze, jako znaczący problemy zidentyfikowano mnogość różnych stosowanych typów konwergencji,

28 Np.P. Wójcik, Dywergencja czy konwergencja: dynamika rozwoju polskich regionów, „Studia Regionalne i Lokalne" nr 2(32), 2008, s. 41-60.

29 O. Cappé, E. Moulines, T. Rydén, Inference in Hidden Markov Models, Springer, New York 2005. 
począwszy od najpopularniejszej i najlepiej umotywowanej od strony teoretycznej konwergencji typu $\beta$, skończywszy na rzadko spotykanych konwergencjach typu $\rho$ czy $\gamma$. Zasadne wydaje się przeprowadzenie analizy, w jakim stopniu koncepcje te pokrywają się, a w szczególności w jaki sposób należy prowadzić dalsze wnioskowanie w sytuacji, gdy poszczególne rodzaje analiz prowadzą do rozbieżnych wniosków. Po drugie, rozbieżności wynikające z analizy konwergencji warunkowej, będące skutkiem trudności z arbitralnym doborem czynników wzrostu do stosowanego modelu, lub też niejednoznacznie potwierdzaną w literaturze adekwatnością procedur bayesowskiego uśredniania oszacowań, wskazują na konieczność dalszej eksploracji tego obszaru i możliwie obiektywne poszukiwanie rozwiązań. Jako dodatkowy element warto rozważyć analizę konwergencji warunkowej innych typów niż $\beta$, przez analogię do zaproponowanej wcześniej przez Próchniaka i Witkowskiego warunkowej konwergencji stochastycznej. Wreszcie jako ostatni kluczowy problem zidentyfikowano kwestię uwzględnienia niestabilności procesów wzrostu gospodarczego w czasie. Jako rozwiązanie zaproponowano wykorzystanie metod opartych na ukrytych łańcuchach Markowa. Można oczekiwać, że zaproponowane rozwiązania będą stanowiły istotną wartość dodaną w badaniach prowadzonych nad konwergencją.

\section{Literatura}

Barro R.J., Economic Growth in a Cross Section of Countries, „Quarterly Journal of Economics" No. 106, 1991, s. 407-443.

Barro R., Sala-i-Martin X., Convergence, „Journal of Political Economy” No. 100, 1992, s. $223-251$.

Batóg J., Konwergencja dochodowa w krajach Unii Europejskiej, Wydawnictwo Naukowe USz, Szczecin 2010.

Bernard A.B., Durlauf S.N., Convergence in International Output, „Journal of Applied Econometrics" No. 10, 1995, s. 97-108.

Boyle G.E., McCarthy T.G., A Simple Measure of $\beta$-Convergence, „Oxford Bulletin Economics and Statistics" No. 59, 1997, s. 257-264.

Cappé O., Moulines E., Rydén T., Inference in Hidden Markov Models, Springer, New York 2005.

Ciccone A., Jarociński M., Determinants of Economic Growth: Will Data Tell?, „American Economic Journal: Macroeconomics" No. 2, 2010, s. 223-247.

Crespo-Cuaresma J., Doppelhofer G., Nonlinearities in Cross-Country Growth Regressions: A Bayesian Averaging of Thresholds (BAT) Approach, "Journal of Macroeconomics" No. 29, 2007, s. 541-554. 
Friedman M.J., Do Old Fallacies Ever Die?, „Journal of Economic Literature” No. 30, 1992, s. 2129-2132.

Furceri D., $\beta$ and $\sigma$-convergence: A Mathematical Relation of Causality, „Economics Letters" No. 89, 2005, s. 212-215.

Gajewski P., Tokarski T., Czy w Polsce występuje efekt konwergencji regionalnej?, „Studia Ekonomiczne" nr 1-2, 2004, s. 45-70.

Islam N., What Have We Learnt from the Convergence Debate?, „Journal of Economic Surveys" No. 17, 2003, s. 309-362.

Lucke B., $\rho$-Convergence, „Economics Letters” No. 99, 2008, s. 439-442.

Moral-Benito E., Determinants of Economic Growth: A Bayesian Panel-Data Approach, „Working Paper” No. 719, CEMFI, Madrid 2010.

Moral-Benito E., Model Averaging in Economics, „Working Paper”, Bank of Spain, Madrid 2011.

Pesaran M.H., A Pair-wise Approach to Testing for Output and Growth Convergence, „Journal of Econometrics" No. 138, 2007, s. 312-355.

Próchniak M., Witkowski B., Alternative Weighting Schemes in Spatial Analysis of GDP Per Capita Convergence, „Metody Ilościowe w Badaniach Ekonomicznych” nr 15(2), 2014, s. 198-208.

Próchniak M., Witkowski B., Konwergencja gospodarcza typu $\beta$ w świetle bayesowskiego uśredniania oszacowań, „Bank i Kredyt” nr 43, 2012, s. 25-58.

Próchniak M., Witkowski B., Real $\beta$ Convergence o Transition Countries - Robust Approach, „Eastern European Economics” No. 51, 2013, s. 6-26.

Próchniak M., Witkowski B., Time Stability of the Beta Convergence among EU Countries: Bayesian Model Averaging Perspective, „Economic Modeling” No. 30, 2013, s. 322-333.

Próchniak M., Witkowski B., Stochastic Convergence of the European Union Countries: A Conditional Approach, „Roczniki Kolegium Analiz Ekonomicznych SGH” nr 39, 2015, s. 41-55.

Quah D.T., Galton's Fallacy and Tests of the Convergence Hypothesis, „Scandinavian Journal of Economics" No. 95, 1993, s. 427-443.

Sala-i-Martin X., The Classical Approach to Convergence Analysis, „Economic Journal” No. 106, 1996, s. 1019-1036.

Sala-i-Martin X., I Just Ran Two Million Regressions, „American Economic Review” No. 87(2), 1997, s. 178-183.

Sala-i-Martin X., On Growth and States, PhD Dissertation, Harvard University 1990.

Sala-i-Martin X., Doppelhofer G., Miller R., Determinants of Long-Term Growth: A Bayesian Averaging of Classical Estimates (BACE) Approach, „American Economic Review” No. 94, 2004, s. 813-835.

Wójcik P., Dywergencja czy konwergencja: dynamika rozwoju polskich regionów, „Studia Regionalne i Lokalne" nr 2(32), 2008, s. 41-60. 


\section{Income-level convergence: strong and weak points of empirical studies}

The paper presents the review of the literature on income-level convergence (catching-up). The analysis includes convergence defined as the tendency toward equalization of income levels between countries. Unlike typical survey papers, the article focuses on the identification of weaknesses in the hitherto empirical studies on convergence. Apart from the standard types of the catching-up process (beta and sigma convergence), papers with the alternative measures of convergence (gamma and rho) are also analyzed. Both these elements constitute the value added of this research. The authors conclude that despite many empirical approaches, there is still much room for proposing new theoretical and empirical methods to analyze the catching-up process. Among others, studies that use hidden Markov models in the analysis of convergence are absent.

Keywords: economic growth, convergence, confluence, income bevel.

\section{Convergence des revenus: atouts et faiblesses des approches existantes}

Le document présente la littérature dédiée à la convergence du niveau de revenu (rattrapage). L'analyse comprend la convergence définie comme une tendance à l'égalisation des niveaux de revenus entre les pays. Contrairement aux enquêtes traditionnelles, l'article met l'accent sur l'identification des faiblesses dans les études empiriques sur la convergence réalisées jusqu'à présent. Outre le processus de rattrapage standars (convergence bêta et sigma), l'article décrit également les documents présentant les mesures alternatives de convergence (gamma et rho). Ces deux éléments constituent la valeur ajoutée de cette recherche. Les auteurs concluent que, malgré de nombreuses approches empiriques, il y a encore beaucoup de place pour proposer de nouvelles méthodes théoriques et empiriques afin d' analyser le processus de rattrapage, telles que, entre autres, les études utilisant les modèles de Markov.

Mots-clés: croissance économique, convergence, similitude, niveau de revenu. 


\section{Конвергенция доходов: сильные и слабые стороны существующих подходов}

В статье представлен обзор литературы, посвященной конвергенции уровня доходов (catching-up). В анализе понятие конвергенции определяется как тенденцию к выравниванию уровней доходов между странами. В отличие от типовых обзорных работ, в статье основное внимание уделяется выявлению недостатков проведенных до сих пор эмпирических исследований по конвергенции. Кроме стандартных типов конвергенции (бета- и сигма-), представлены также работы, использующие альтернативные меры конвергенции (гамма- и ро-), что показывает ценность данной статьи. Авторы делают вывод, что, несмотря на множество эмпирических подходов, существует еще много возможностей для предложения новых теоретических и эмпирических методов анализа этого процесса. В частности, отсутствуют исследования, которые используют в анализе конвергенции скрытые марковские модели.

Ключевые слова: экономический рост, конвергенция, уровень дохода. 